Canadian University Music Review

Canadian University Music Review

Revue de musique des universités canadiennes

\title{
The Gender Stereotyping of Musical Instruments in the Western Tradition
}

\section{Rita Steblin}

Volume 16, numéro 1, 1995

Voices of Women: Essays in Honour of Violet Archer

Voix de femmes : mélanges offerts à Violet Archer

URI : https://id.erudit.org/iderudit/1014420ar

DOI : https://doi.org/10.7202/1014420ar

Aller au sommaire du numéro

\section{Éditeur(s)}

Canadian University Music Society / Société de musique des universités canadiennes

\section{ISSN}

0710-0353 (imprimé)

2291-2436 (numérique)

Découvrir la revue

Citer cet article

Steblin, R. (1995). The Gender Stereotyping of Musical Instruments in the Western Tradition. Canadian University Music Review / Revue de musique des universités canadiennes, 16(1), 128-144. https://doi.org/10.7202/1014420ar

\section{Résumé de l'article}

The sexual stereotyping of musical instruments in Italian, German, and English society from the beginning of the Renaissance period to the end of the nineteenth century is the object of this essay. Through evidence gleaned from iconography and a variety of written documents, the author demonstrates how the gender association of musical instruments virtually eliminated female participation from important musical activities, ensuring the male domination of the art and preventing women from becoming prominent composers.
All Rights Reserved @ Canadian University Music Society / Société de musique des universités canadiennes, 1995
Ce document est protégé par la loi sur le droit d'auteur. L'utilisation des services d'Érudit (y compris la reproduction) est assujettie à sa politique d'utilisation que vous pouvez consulter en ligne.

https://apropos.erudit.org/fr/usagers/politique-dutilisation/ 


\section{THE GENDER STEREOTYPING OF MUSICAL INSTRUMENTS IN THE WESTERN TRADITION}

\section{Rita Steblin}

The gender stereotyping of musical instruments-that is, the labelling of instruments as being primarily male or female-is an aspect of the sociology of music which has had an enormous impact on the role of women in music history. ${ }^{1}$ The question is often put: why were there no great women composers? This essay will attempt to answer that question in part, by showing how the gender association of musical instruments virtually eliminated female participation from important musical activities, which in turn ensured the male domination of the art.

An early witness to the gender division between instruments was Luca della Robbia's masterpiece, the "Cantoria"-a relief sculpture carved between 1432 and 1438 in the organ loft of the Cathedral in Florence. Figure 1 shows the four reliefs on the front of the parapet. These illustrate those verses of Psalm 150 which read: "Praise him with the sound of the trumpet: praise him with the psaltery and harp. Praise him with the timbrel [tambourine, frame drum] and dance." 2 Figure 1a shows the trumpet played by boys and the psaltery played by girls. Figure $1 \mathrm{~b}$ shows the harp (actually citharas or lutes) played by girls and the timbrel (here a frame drum) - along with a pipe-played by boys. The boys' instruments are raucous and noisy and are accompanied by vigorous dancers. Clearly, the trumpets and drums have an inciting, active effect. The opposite effect, one of calm repose, is seen in the reliefs with girl musicians. Their instruments-psalteries and lutes-are quiet, plucked stringed instruments, suitable for accompanying song. The gender division between active and passive is quite evident here.

Della Robbia's visual documentation of gender stereotyping is reinforced by the discussion of correct social behaviour in Baldesar Castiglione's The Book of the Courtier (1528). This book was extremely influential in dictating proper female conduct for many centuries to come. Castiglione writes that

it is not seemly for a woman to handle weapons, ride, play tennis, wrestle, and do many other things that are suited to men.... Not only would I not have her engage in such robust and strenuous manly exercises, but even those that are becoming to

1 This article, written in early 1988 and based on scholarship available at that time, was inspired by the knowledge that Violet Archer played percussion with the Montreal Women's Symphony Orchestra from 1940 to 1948 .

2Holy Bible, Authorized King James Version, Psalm 150:3-4. For a recent discussion of the Cantoria, see John Pope-Hennessy, Luca della Robbia (Ithaca: Cornell University Press, 1980), 19-29. 

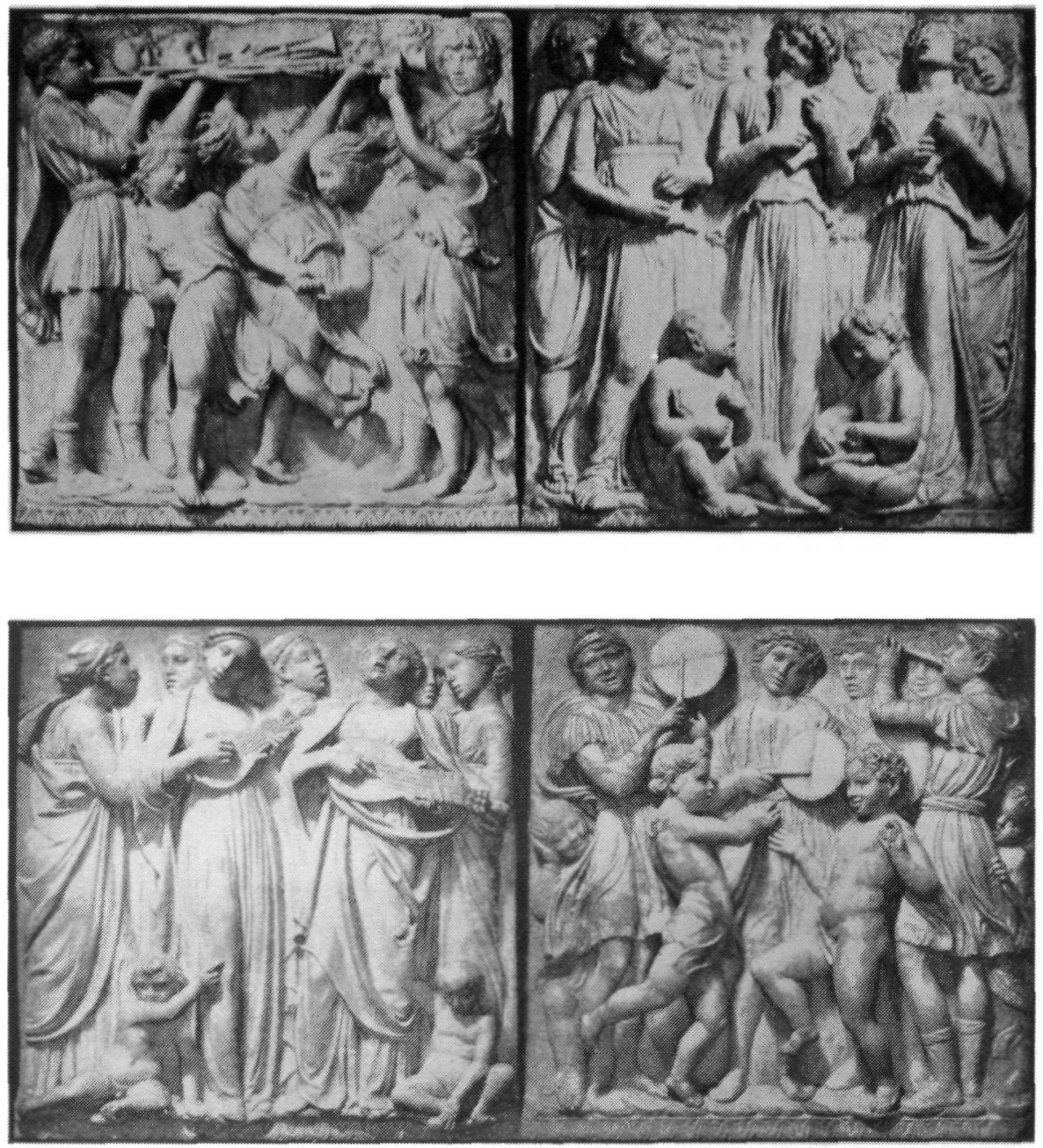

Figure 1. Luca della Robbia (1400?-1482), "Cantoria," marble, Museo dell'Opera del Duomo, Florence. Source: Die Musik 11, no. 14 (April 1912): 128. 1a: Trumpeters [top left-hand]; psaltery players [top right-hand]; $1 \mathrm{~b}$ : cithara players [bottom left-hand]; drummers

a woman I would have her practise in a measured way and with that gentle delicacy that we have said befits her; ... the musical instruments that she plays ought in my opinion to be appropriate to this intent. Consider what an ungainly thing it would be to see a woman playing drums, fifes, trumpets, or other like instruments; and this because their harshness hides and removes that suave gentleness which so adorns a woman in her every act. ${ }^{3}$

3 Baldesar Castiglione, The Book of the Courtier, trans. Charles S. Singleton (Garden City, N.Y.: Doubleday, 1959), 210. 
Drums, fifes, and trumpets: these are the same instruments that Della Robbia had assigned a century earlier to male players in his Cantoria reliefs. Drums, and in general all percussion instruments, were considered inappropriate for women because they required "energetic and violent movements"; fifes, trumpets, and in general all wind instruments were disallowed because they distorted the face-thus disturbing the feminine ideal of "suave gentleness." 4

According to Edith Borroff, in an article on women composers, the Renaissance was "a step backwards for women." 5 The growth of humanism and the development of a new social structure in Italy "deprived women of power, created a patriarchal culture, and, in general, set women back in their quest for human liberty and autonomy." 6 Educational opportunities for women declined, and their creative activities were restricted. Women were now confined to the home.

It was not always this way. Borroff writes that the medieval era was "a period of productivity, of professional women-including composers." The Provençal language had a term "trobairitz," meaning female troubadour, and Old English had such words as "hearpestre," a female harper, and "timpestere," a female drum player. The 1321 incorporation of thirty-seven "Menestreus et Menestrelles, jongleurs et jongleresses" living in the city of Paris includes at least eight names identifiable as belonging to women. Medieval illustrations show women playing rebecs and fiedels - bowed stringed instruments-as well as such percussion instruments as clappers or handbells-thus, noisy instruments requiring vigorous movements. ${ }^{8}$

In fact, if we go back to the ancient classical era we find quite often that women are shown playing the aulos-the shrill, double-reed ancestor of our oboe-and men are shown playing the harp or lyre. ${ }^{9}$ (This is illustrated by figure 2, which shows two Grecian marble reliefs from ca. 470 B. C.) This was no doubt due to the fact that the stringed lyre, along with its Dorian harmonies, was associated with the refined and civilized cult of Apollo, and according to Aristotle, had a "specially manly character," whereas the aulos and its Phrygian mode were associated with the orgiastic rites of Dionysus and had a "violently exciting and emotional" character. ${ }^{10}$ In particular, the aulos was associated with

4 Castiglione (ibid., 105) refers to the classical myth of Minerva abandoning the pipes in disgust upon catching sight of her twisted features reflected in a pool of water.

5Edith Borroff, "Women Composers: Reminiscence and History," College Music Symposium 15 (1975): 29.

6Bari Watkins, "Women and History," Change, May 1974: 20, as quoted in Borroff, "Women Composers: Reminiscence and History," 29.

7Borroff, "Women Composers: Reminiscence and History," 28.

$8 \mathrm{Ibid} .$, Music in Europe and the United States (Englewood Cliffs, N.J.: Prentice-Hall, 1971), 42-44. See also the illustrations and fine discussion of female instrumentalists in Maria V. Coldwell, "Jougleresses and Trobairitz: Secular Musicians in Medieval France," in Women Making Music: The Western Art Tradition, 1150-1950, ed. Jane Bowers and Judith Tick (Urbana: University of Illinois Press, 1986), 39-61.

9See the illustrations in George Kinsky, Album Musical (Paris: Delagrave, 1930), 10-19. Here men and women are shown playing both the aulos and the lyre.

10 See the excerpt from Aristotle's The Politics, in Oliver Strunk, Source Readings in Music History: Antiquity and the Middle Ages (New York: W. W. Norton, 1965), 23. 
the frenzied maenads, the female followers of Bacchus. It is quite revealing, therefore, that in the Renaissance development of musical stereotypes, stringed instruments were assigned to women and wind instruments to men. This seeming "role reversal" points to the arbitrary nature of these stereotypes. (In Biblical times it was King David who played the harp and Miriam, sister of Aaron, who played the timbrel, a percussion instrument.)
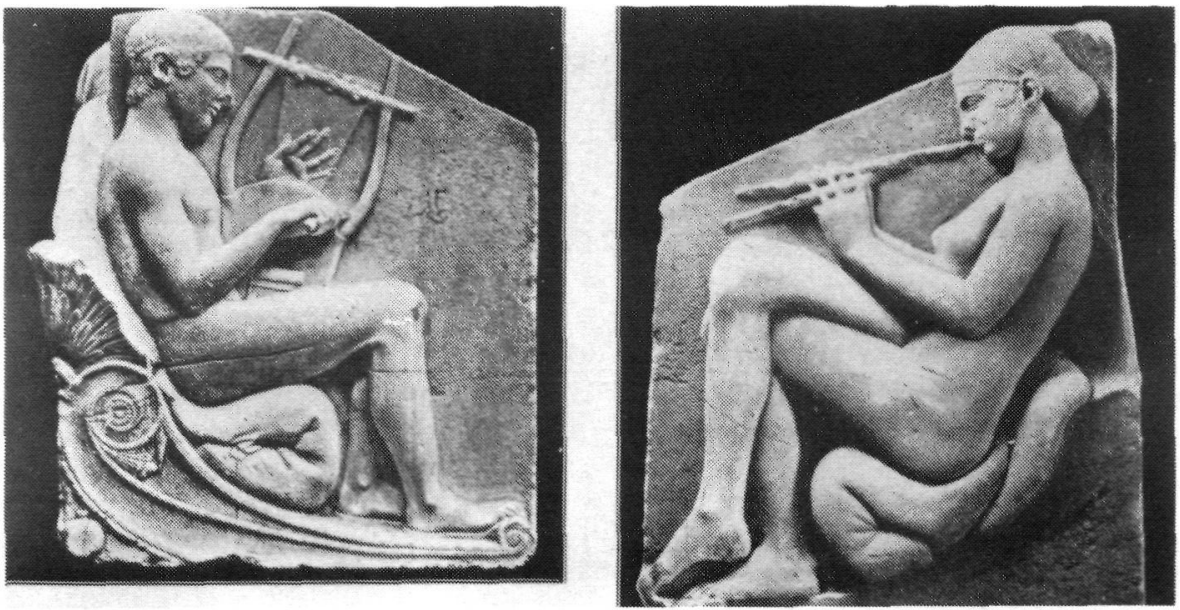

Figure 2. a) Lyre-player, marble, ca. 465 B. C., Museum of Fine Arts, Boston [left-hand]; $b$ ) Courtesan playing the aulos, marble, ca. 470 B. C., Museum of the Thermes, Rome. Source: George Kinsky, Album Musical (Paris: Delagrave, 1930), 13 [right-hand].

If women were proscribed from playing wind instruments, what do we make of such famous Renaissance images as Tobias Stimmer's series of woodcuts of nine women musicians (ca. 1570-77)? Figure 3 shows two of these women playing such male instruments as the bass shawm and trumpet.

A closer examination, however, reveals that Stimmer's nine elegantlydressed women are not meant to represent normal women of the time, but rather the nine muses of classical Greek mythology. This is made clear from the caption to the "enigmatic" tenth muse-a horrible old woman playing the pot, lid, and spoon-which was Stimmer's sarcastic comment that "commercial" music had nothing to do with the nine muses of "classical" music. The captions are sprinkled with Classical references and are meant to show the origins of the various instruments. A Renaissance woman would never have been seen playing the trumpet. This instrument had long been associated with the military and was used to rouse the troops and give signals in battle. A soldier's career was a male prerogative only, and there would have been no opportunity for a woman to learn or to play this instrument in a military setting. There was also no opportunity for women to learn the special clarino technique — and partake in the high privileges and salaries of the royal trumpeteers-since this was all controlled by an exclusive male guild system. Women also did not play with the town waits. 

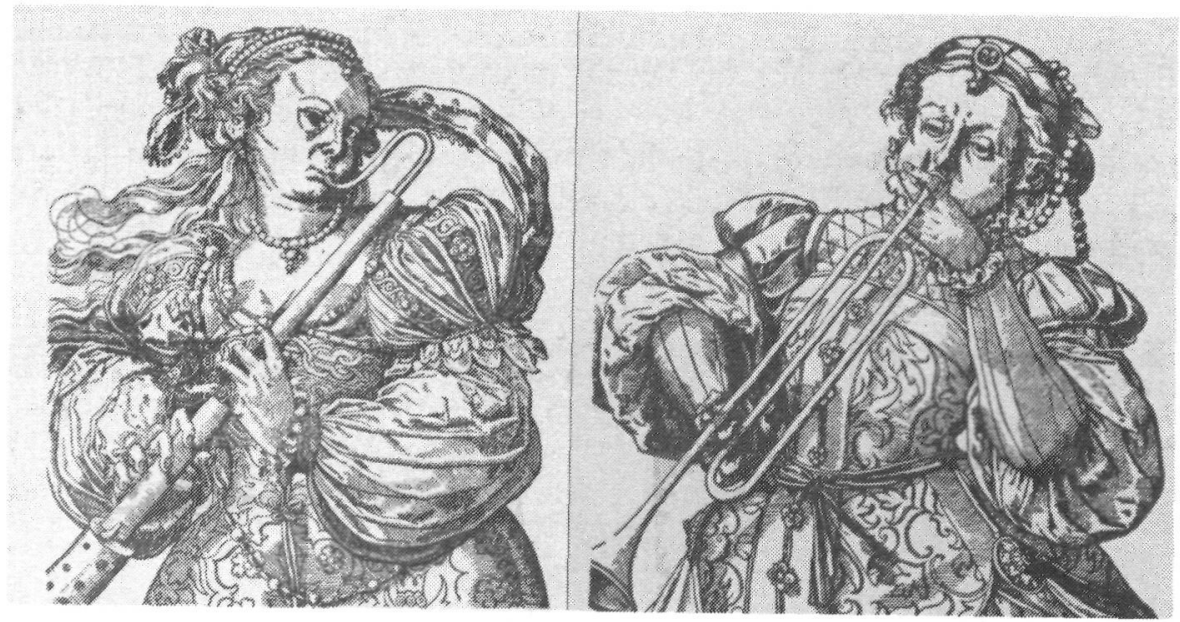

Figure 3. Tobias Stimmer (1539-84), "Woman Musicians," woodcut, New York Public Library. Source: La Rue and Holland, "Stimmer's Women Musicians," pl. 177-78. 3a: Bass shawm player [left-hand]; $3 b$ : trumpeter [right-hand].

Therefore, it was really only in the mythical world of the artist that women could play trumpets. A similar situation existed for the horn, an instrument associated primarily with the exclusively male sport of hunting. Any woman playing the horn in a painting was most likely associated with Diana, the mythical patroness of the hunt.

The legend of St. Cecilia also led to allegorical misrepresentations of the truth about female access to musical instruments. This Christian patron saint of music was usually depicted playing the organ. ${ }^{11}$ However, women were generally excluded from the career of church organist, since active positions in the church were reserved for males only. The apostle Paul's admonition "mulieres in ecclesiis taceant" (women should keep silent in church) was used by the ecclesiastical authorities as justification for banning women from the musical life of the church. It was only in the convents that nuns, secluded and without real power, were able to make music as part of religious worship. Thus, in allegorical art, St. Cecilia could be depicted playing the "king" of instruments, but in reality, women were effectively banned from performing on the organ. Figure 4 shows a detail from the title page to Adam Gumpelzhaimer's Neue Teutsche Geistliche Lieder of 1591 with the figure of a St. Cecilia-like "Musica" at the organ surrounded by eight female musicians. Since these are the nine muses, they are allowed to play restricted "male" instruments. Thus, such illustrations do not reflect current social practice.

Women were also discouraged from playing the violin. No doubt this was due to the same attitude - a fear of the loss of respectability-which banned

11 See the many illustrations in Albert P. de Mirimonde, Sainte-Cécile: métamorphoses d'un thème musical (Geneva: Minkoff, 1974). 


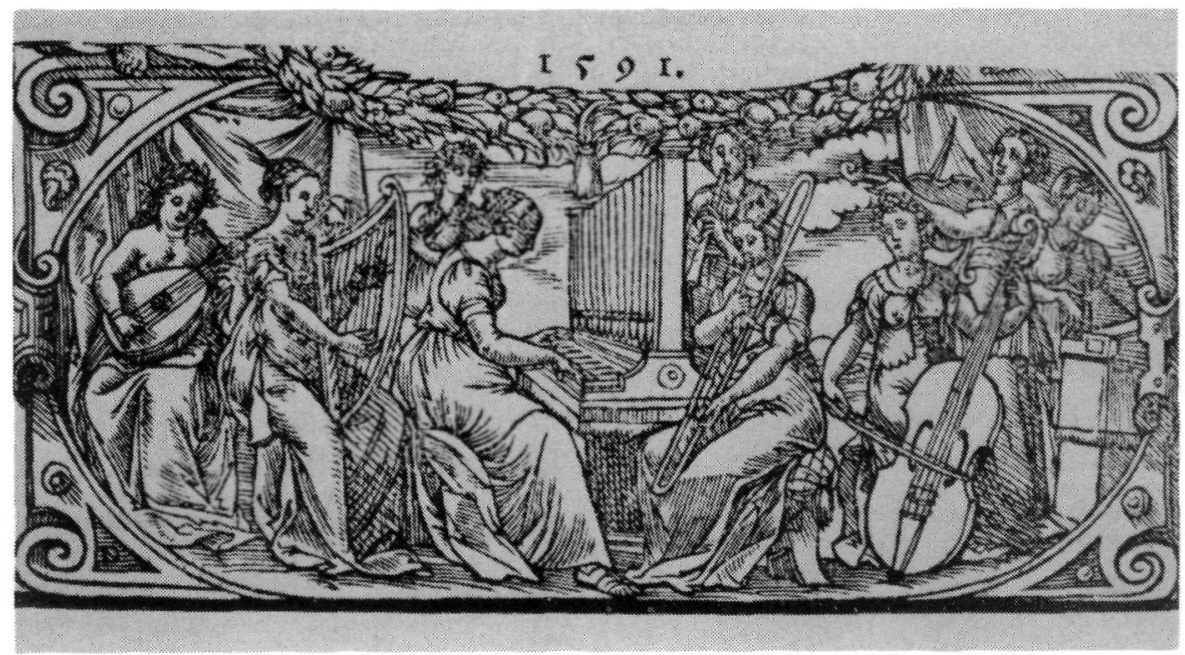

Figure 4. Adam Gumpelzhaimer, Neue Teutsche Geistliche Lieder (Augsburg, 1591), title page. Source: Tom L. Naylor, The Trumpet \& Trombone in Graphic Arts, 1500-1800 (Nashville: The Brass Press, 1979), fig. 221.

women from the stage. It was very soon after the development of the violin ca. 1550 in northern Italy that this instrument replaced the pipes and shawm as the instrument of the dance. It was in this connection that the violin became associated with the low-class "Bier-Fiedler" type of musician. Women attended dances, but they did not play for dances. Even after the violin had gained respectability for its role in the string quartet and symphony orchestra, the association with the dance floor was enough to prohibit women from taking up the violin. A review in the London Times of 1817 objected to a concert at which a young girl had performed a violin concerto, on the grounds that the violin was "unsuitable to the prescriptive habits and accomplishments of a female."12 Playing the violoncello was especially frowned upon because the woman would have to spread her legs!

What instruments then were women allowed to play? A mid-sixteenth-century account of the education of two sisters who were "boarded out" reads: they "are broughte uppe in writinge, readinge, sewinge, both white worke and blacke worke, and playenge of the lute and virginalls, as yonge gentlewomen and maydes of theire ages are accustomed." 13 Another case history of two aristocratic English sisters, sent in the mid-1530s to be educated in France, shows that one "learned to play upon a pair of virginals sent from England" and the other "studied lute, virginal, and spinet." 14 An eighteenth-century report decrying the

12 As quoted in Nicholas Temperley, "Domestic Music in England between 1800 and 1860," Proceedings of the Royal Music Association 85 (1958-59): 35.

13Dorothy Gardiner, English Girlhood at School: A Study of Women's Education through Twelve Centuries (London: Oxford University Press, 1929), 120.

14 Ibid., 123. 
education received at country boarding schools remarks that the girls learnt "to quaver instead of singing, hop instead of dancing, and rumble the virginals, scratch the lute and rake the ghitar." 15

It is clear from these and many other sources that the preferred instruments for women were plucked stringed instruments, and that the most popular of all was the virginal. Even the earliest explanations of this small rectangular version of the harpsichord define it as an instrument associated with young girls. Paulus Paulirinus in the Tractatus de musica (ca. 1460) writes: "they are called virginals because of the soft, sweet, and mild quality of their tone, like the voice of a young lady." 16 The Parthenia of 1611 , the earliest music printed for the virginal, has a title-page featuring a demure young lady playing on the instrument, under the heading "Parthenia or The Maydenhead of the first musicke that ever was printed for the Virginalls"- thus, a pun involving the nature of virgins. ${ }^{17}$ Two early English dictionaries also define the instrument in terms of virgins. The entry in John Minsheu's Ductor in Linguas (1617) reads: "Virginalls, Instrumentum Musicum propriè Virginum ... so called because virgins and maidens play on them; Latin, Clavicymbalum, Cymbaleum Virginaeum."18 Thomas Blount's Glossographia of 1656 has the following entry: "Virginal (Virginalis) Maidenly, Virgin-like; hence the name of that Musical Instrument, called Virginals, because Maids and Virgins do most commonly play on them."19

Although "virginal" was mainly an English-usage term, there is some evidence that, when the word was translated into other languages, it retained the association with young women. Francis Galpin writes concerning the virginals: "In 1581, too, Vincentio Galilei calls it the Clavichordium matronale, using the word 'clavichord' in the Italian sense for any keyboard form." ${ }^{20}$ Heinrich Schütz, in his work for four choirs Veni, Sancte Spiritus, SWV 475 (1620s), designates the continuo instrument for the third choir as "FrawenZimmer" [lady]. Werner Breig, the editor of the work in the Schütz Neue Ausgabe, states that this must be a German translation of the word "virginal."21 Johann Gottfried Walther's important Musikalisches Lexikon of 1732 contains the entry: "Virginale [lat.] ein Clavier vors Frauenzimmer" [a keyboard instrument for the ladies]. Concerning French usage of the instrument, Sibyl Marcuse writes that "the demoiselle [young lady], otherwise unidentified, was included in a list of

15 Ibid., 341.

16As quoted in F. E. Kirby, A Short History of Keyboard Music (New York: The Free Press, 1966), 15.

17This title page is reproduced in Donald Jay Grout, A History of Western Music, 3rd ed. with Claude V. Palisca (New York: W. W. Norton, 1980), 285. See Mirimonde, Sainte-Cécile: métamorphoses d'un thème musical, 148, for the model, "St. Cecilia accompanying two angel singers," and for the Parthenia illustration.

18 As quoted in A. J. Hipkins, A Description and History of the Pianoforte and of the Older Keyboard Stringed Instruments (London: Novello, [1877]), 69.

19 Thomas Blount, Glossographia (London: Thomas Newcomb, 1656; reprint, Menston, Yorkshire: Scolar Press, 1969).

20Francis W. Galpin, A Textbook of European Musical Instruments (London: Williams \& Norgate, 1937), 106

21 Heinrich Schütz, Neue Ausgabe sämtlicher Werke, vol. 32, ed. Werner Breig (Kassel: Bärenreiter, 1971), 177-78. 
musical instruments played at the time of its compilation by the Académie des Sciences in 1702."22

In spite of the long tradition of the virginal as an instrument for females, the origin of the name has recently been disputed. According to Curt Sachs: "The name virginal has mistakenly been connected with virginity. ... The word probably is related to medieval Latin virga, "rod, jack." 23 This interpretation appears in Karl Geiringer's book Musical Instruments of 1945 and in Paul Henry Lang's A Pictorial History of Music of 1960 and has been adopted by many of the recent writers on the harpsichord. ${ }^{24} \mathrm{It}$ is almost as if contemporary scholars had trouble accepting this instrument in terms of its past gender stereotype and are relieved to find another less troubling source for the word "virginal." Edwin Ripin, however, in the New Grove article "Virginal" calls the Sachs derivation of the term "unproved," and F. E. Kirby writes that there are etymological difficulties with this explanation "since virgo-virgalis (related to rod, thorn, or jack) could not be the same as virgo-virginalis (related to virgin)." ${ }^{25}$ In my opinion, it is wrong for us to rewrite history in an attempt to assuage the twentieth-century male conscience.

A novel explanation for the etymology of the term "virginal" was proposed in 1964 by Sibyl Marcuse. ${ }^{26}$ She argues that the virginalwas a vernacular translation of "cembalo," an instrument traditionally played by women. This was originally the tambourine or timbrel, as in the Biblical verse: "And Miriam the prophetess, the sister of Aaron, took a timbrel in her hand; and all the women went out after her with timbrels and with dances" (Exodus 15:20). Zarlino still defined the cembalo as a tambourine, and in the index to his Sopplimenti musicali (1588) cites this instrument as "Cembalo, Istrumento da donne" [instrument of women]. A confusion of etymons "tympanon" [drum, later dulcimer (percussive stringed instrument)] and "cymbalon" [cymbal, later dulcimer] led to the ambiguity in the word "cembalo" [tambourine, later harpsichord]. According to Marcuse, since women traditionally played the "cembalo," the virginal was so named because of the continuing association of "cembalo" [now as a "clavicembalo," a keyed stringed instrument] with women.

The iconographical evidence is certainly overwhelming in showing that the virginal was an instrument associated with young women. Gustav Leonhardt, in an article about Flemish virginals of the seventeenth century, names twentyfive different Dutch masters of that century who painted young ladies playing

22Sibyl Marcuse, A Survey of Musical Instruments (New York: Harper \& Row, 1975), 297.

23 Curt Sachs, The History of Musical Instruments (New York: W. W. Norton, 1940), 335.

24Karl Geiringer, Musical Instruments: Their History in Western Culture from the Stone Age to the Present Day, 2nd ed., trans. Bernard Miall (London: George Allen \& Unwin, 1945), 128; Paul Henry Lang and Otto Bettmann, A Pictorial History of Music (New York: W. W. Norton, 1960), 61. See also the excellent iconographical study by Lucas van Dijck and Ton Koopman, The Harpsichord in Dutch Art before 1800 (Zutphen: De Walburg Pers, 1987), where we read in the introduction: "The word virginal is derived from virga (quill) used as a pars pro toto."

25 Kirby, A Short History of Keyboard Music, 15.

26 Sibyl Marcuse, Musical Instruments: A Comprehensive Dictionary (Garden City, N. Y.: Doubleday, 1964), 85, 581. 
the virginal. ${ }^{27}$ Ton Koopman, in his comprehensive study on the harpsichord in Dutch art before 1800, writes: "It is interesting that about $90 \%$ of the keyboard players pictured are women and girls. There are so few men seen playing, were keyboards considered strictly feminine domain?"28 This brings up the issue of whether or not male performers on the virginal were considered to be effeminate-a kind of reverse stereotyping. This does not appear to have been the case, and the greatest composers of the time-Sweelinck, Byrd, Bull, Gibbons, and Blow-were performers on the virginal. One can safely say that men had free access to all instruments.

A major iconographical study by Richard D. Leppert on domestic musical life in eighteenth-century England amasses a great deal of evidence to show "how musical practices helped to assure and preserve male domination of women by limiting female activity to the home." 29 In portraits of family groups the women are usually shown seated at the virginal, dressed in indoor finery and with a caged bird nearby, while the male members are dressed in outdoor clothing and carry such military implements as swords or drums. The men were free to pursue their careers in the world at large, but the women were confined to the home (like the bird in a cage). Figure 5 shows an early-eighteenth-century drawing by a woman, Lady Dorothy Savile, of a young girl playing a spinet in a windowless room. The symbolism here is apparent, in that the girl is confined like the caged owl, tormented by free-flying birds, and hoping for freedom. ${ }^{30}$ Even the German word for "lady"Frauenzimmer - associated her with a Zimmer or room in a house. The virginal (and later piano) was, of course, the most house-bound of instruments.

The sociological purpose in keeping a young woman at home, practising the virginal, was to ensure her marriageability-and thus eventually to relieve the family of the financial burden of an unwed daughter. There was a great desire to "marry well," and it became a custom to display a daughter's modesty, beauty, and talent to prospective suitors by having her play on the virginal. The level of musical achievement was low-just enough to keep the daughter occupied before marriage-since it was expected that she would lose interest after marriage. Thomas Dekker's Guls Hornebooke (1609), in speaking of a young lady's education, tells us that though she might have no leisure for such things when married, the young gentlewoman should be able "to read and write, to play upon the virginals, lute and cittern [a form of guitar]: and to read pricksong at first sight." 31 An English conduct manual of 1781 reports that "it is common to teach girls the harpsichord, which shows a pretty hand and a nimble finger, without ever thinking whether they have a genius for music, or even an ear. It serves indeed

27Gustav Leonhardt, "In Praise of Flemish Virginals of the Seventeenth Century," in Keyboard Instruments: Studies in Keyboard Organology, ed. Edward M. Ripin (Edinburgh: Edinburgh University Press, 1971), 43-46.

28 Van Dijck and Koopman, The Harpsichord in Dutch Art before 1800, last page of introduction.

29 Richard D. Leppert, "Men, Women, and Music at Home: The Influence of Cultural Values on Musical Life in Eighteenth-Century England," Imago Musicae 2 (1985): 53.

30 See ibid., 112-13, for Leppert's discussion of Savile's drawing.

31 William Chappell, Popular Music of the Olden Time (London: Cramer, Beale \& Chappell, [1859], 1:100, as quoted in Thurston Dart, "The Cittern and Its English Music," The Galpin Society Journal 1 (1948): 49. 


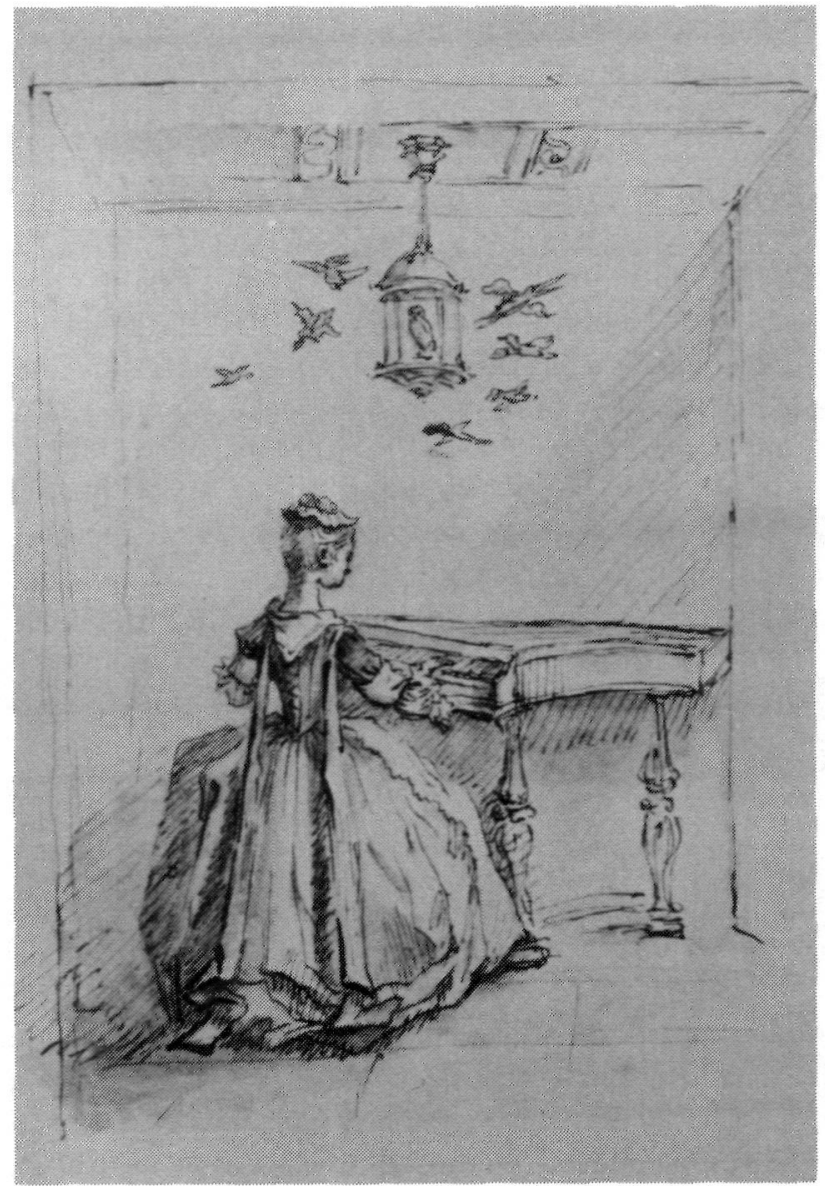

Figure 5. Lady Dorothy Savile, Countess of Burlington (1699-1758), "Girl at Spinet with an Owl in a Cage," pen and brown wash over pencil, Chatworth/Kent, Devonshire Collection, Drawing Album no. 26, p. 12. Source: Richard D. Leppert, "Men, Women, and Music at Home," Imago Musicae 2 (1985), fig. 46.

to fill a gap in time, which some parents are at a loss how otherwise to employ." 32 In the nineteenth century, it became a sign of middle-class prestige to have the daughters play the piano. Alfred Loesser describes the situation aptly in his chapter "The Claviers Are Feminine": "There she could sit, gentle and genteel, and be an outward symbol of her family's ability to pay for her education and her decorativeness, of its striving for culture and the graces of life, of its pride in the fact that she did not have to work and that she did not 'run after' men." 33

32Henry Home and Lord Kames, Loose Hints upon Education (Edinburgh and London, 1781), 244, as quoted in Leppert, "Men, Women, and Music at Home," 83.

33 Alfred Loesser, Men, Women and Pianos: A Social History (New York: Simon and Schuster, 1954), 65. 
A study by Annemarie Krille of the musical education of the German woman, from 1750 to 1820 , confirms that the piano [Klavier] first of all, and secondly the lute, zither and harp were recommended as women's instruments. ${ }^{34}$ She cites the following advice from Johann Daniel Hensel's Das Wohlgezogene Frauenzimmer (Rostock, 1767): "Since most young ladies [junge Frauenzimmer] are taught to play keyboard instruments [Clavier, Flügel], the zither and lute, so I hope that you too will learn to play on all of these instruments, but mainly on the first of these." ${ }^{35}$ According to Krille, the instruments that German pedagogues deemed unsuitable for women were the flute, the violin, the violoncello and the organ. ${ }^{36}$ One of these pedagogues, Karl Heinrich Heydenreich, advises in his book Der Privaterzieher of 1800: "It becomes a young lady very well when she learns to play the piano: she possesses thereby a pleasant talent, an ornament moreover; but to play on the violin or organ is not compatible with the grace of the female sex. ... The arm movements which violin players must make and the faces which they pull would do unfailing harm to femininity." 37 These are the same arguments-energetic movements and facial distortions harm female grace-which Castiglione used in 1528 .

The male attitude towards gender stereotyping of musical instruments is most clearly presented in an article entitled "Vom Kostüm des Frauenzimmer Spielens," which appeared anonymously in 1784 , but which has now been attributed to the pastor, composer, and writer on music Carl Ludwig Junker. ${ }^{38}$ The article has the friendly tone of "fatherly advice" and even admits that the restrictions on instruments have caused a regrettable loss to music of many fine performers on the unsuitable instruments that the female sex could have produced were these restrictions not in place. Nevertheless, Junker maintains that "certain instruments are not meant for ladies. ... It is to be wished, for example, that the horn, the violoncello, the contrabass, the bassoon, the trumpet be played by men only." Junker gives precise reasons for this point of view, which he divides, sermon-like, under three main headings. The first

arises from the feeling of unsuitability which comes from the association of ideas between bodily movements and fashion in clothing. ... We find it ridiculous when we catch sight of a lady wearing a large skirt [Poschen] or even worse, a crinoline [Reifrok], at the double bass; ridiculous when we see her playing the violin with large sleeves moving back and forth-ridiculous when we see her blowing the horn in a fancy hair-do [Fontage].

34 Annemarie Krille. Beiträge zur Geschichte der Musikerziehung und Musikübung der deutschen Frau (von 1750 bis 1820) (Berlin: Triltsch \& Huther, 1938), 122-23.

35 Ibid., 123 n. 44.

36 Ibid., 128.

37 Ibid., 129-30.

38 [Carl Ludwig Junker], "Vom Kostüm des Frauenzimmer Spielens," Musikalischer Almanach auf das Jahr 1784 (Freiburg, [1784]), 85-99. See the discussion of this article in Freia Hoffmann, "Klang und Geschlecht," Neue Zeitschrift für Musik 145, no. 12 (1984): 11-16. 
A woman's duty is to keep quiet. Yet, the string instruments often require a quick, vigorous, powerful movement, which does not sit well with the recognized weakness of the female sex. Such hefty movements might lead to the unwelcome thought that the female player in question has a choleric temperament.

The second point of Junker's sermon is that an uneasy feeling arises when the nature of the instrument does not fit together with the acknowledged characteristic of the female sex-weakness. By "nature," Junker is referring to the affective meaning traditionally assigned to certain instruments, an affective meaning created in part by the tone quality of the instrument and in part by the associative ideas that occur to the listener. For example, trumpets and drums evoke military associations, while horns suggest the hunt. These activities conflict with the "weakness" of the female sex; thus, these instruments are unsuitable for ladies to play.

Junker's third point concerns the incompatibility between the position of the body in playing an instrument and proper female decorum. Thus, performing on the violoncello involves pressing of the breast, when playing near the bridge, and spreading of the legs, "which for thousands would arouse images which ought not to be aroused." To play on such an instrument, causing immoral thoughts, would be most improper.

That such views were widely held is evident from many sources, in particular, caricatures. In a series on musical fools by the early-eighteenth-century sermonizer Abraham a Sancta Clara there is a cartoon "Musicirende-Närzin" [music-making fool], which depicts a woman playing the viola da gamba in the company of a male fool. The rhymed caption accompanying this illustration ends with the lines: "Der Fidel-Bogen steht nit woll, / Wo man Koch-Löffel finden soll" [The fiddle bow ought not to sound, / Where the cook's ladle should be found].$^{39}$ The message here is clear: a woman's place is in the kitchen. Even in the late nineteenth century, women were still being laughed at for attempting to break away from their traditional domain. Figures 6 and 7, cartoons from Germany 1889 and England 1891 , poke fun at the notion of women playing the violoncello and double-bass respectively, by ridiculing female fashions. It would require a great deal of courage to perform on these "masculine" instruments in the face of such strong societal pressure.

The instruments that Junker recommends as suitable for ladies to play-the "clavier," lute, zither, and harp-all have soft, delicate plucked stringed sounds and serve moreover primarily as accompaniment instruments. Thus, they reinforced the prevailing notion that the female sex was "weak" and "secondary." The strong soloistic instruments, such as the violin, oboe, or trumpet, were reserved for males only. This rigid gender division between instruments reflected the roles of the sexes in society: the men (soloists or leaders) held the positions of power while the women (accompanists or followers) did as they were told-were subservient. The only opportunities for women to make music

39 The caricature with text is reproduced in Karl Storck, Musik und Musiker in Karikatur und Satire (Oldenburg: Gerhard Stalling, 1910), 119. 


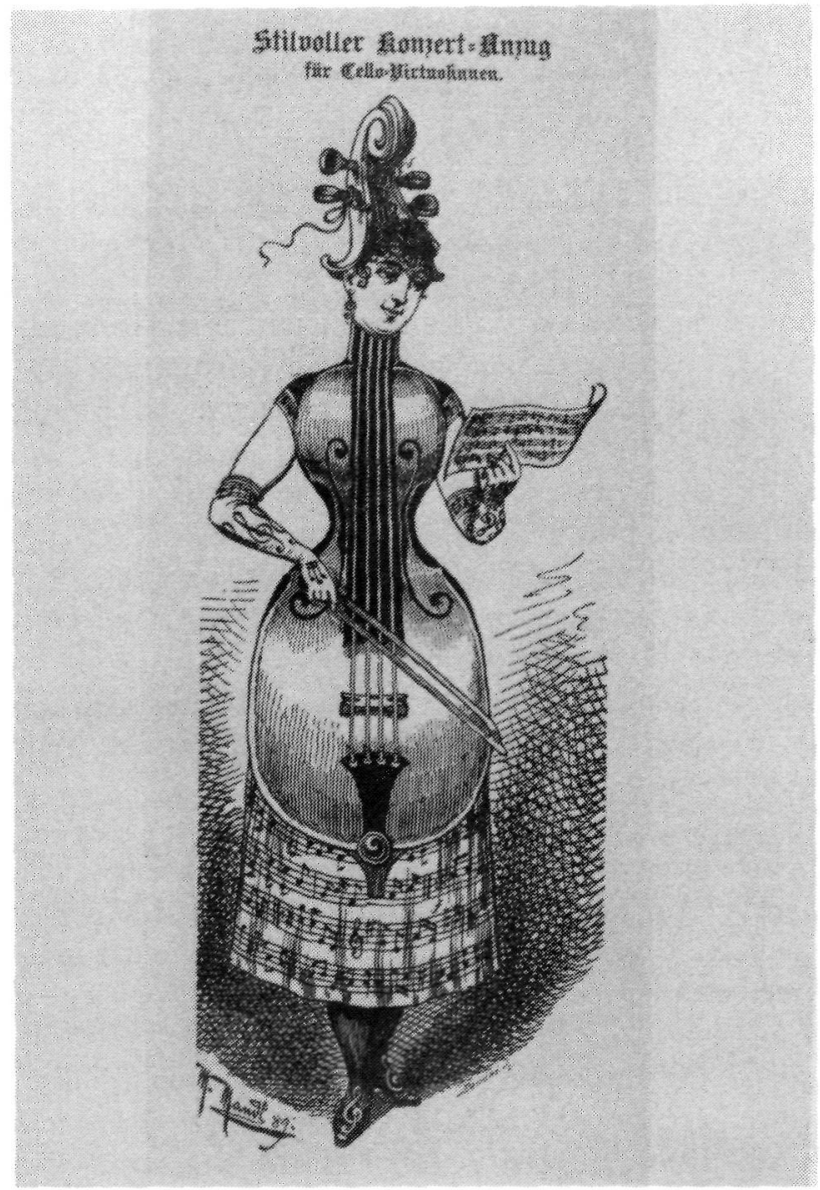

Figure 6. M. Mandl, "Stilvoller Konzert-Anzug für Cello-Virtuosinnen," Ulk (Berlin, 1889). Source: Hans Christoph Worbs, Das Dampfkonzert: Musik und Musikleben des 19. Jahrhunderts in der Karikatur (Wilhelmshaven: Heinrichshofen, 1982), 225.

were in the home, as part of domestic entertainment: professional positions in music-in the church, at court, or in theatre orchestras-were for males only.

Although the "clavier"- whether as virginal, harpsichord, clavichord, or piano-always remained the preeminent female instrument, the other suitable instruments-lutes and viols, harps, and guitars-waxed and waned in popularity according to the current fashion. The lutes and viols, for example, were most popular during the Renaissance and Baroque eras, in particular, the treble and pardessus forms of the viol-small instruments that could be held in the lap. In the mid-eighteenth century the vielle or hurdy-gurdy became popular. This corresponded with the fad for all things rustic or pastoral-a fad that saw 


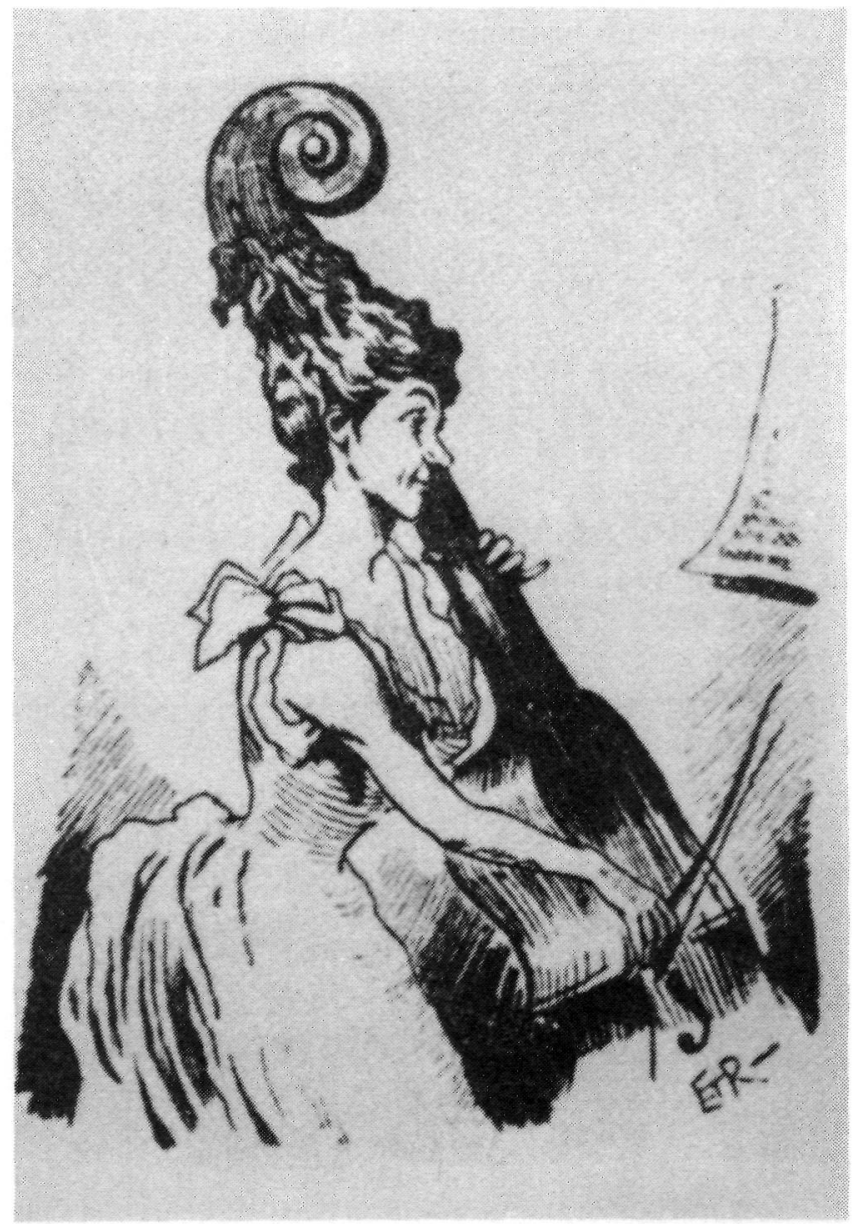

Figure 7. "Two Heads Better than One," Punch (London, 1891). Source: Worbs, Das Dampfkonzert: Musik und Musikleben des 19. Jahrhunderts in der Karikatur (Wilhelmshaven: Heinrichshofen, 1982), 224.

aristocratic ladies pretending to be milk maids. In the generation of Marie-Antoinette the harp came into vogue, and there are many portraits from this era of gracious ladies draped over a harp. Since Biblical times, when David cured King Saul's madness by strumming on the harp, this instrument has been associated with soothing, calming emotions and thus was ideally suited to become a stereotypically female instrument. The fact that the nineteenth-century orchestral harp was a large, heavy instrument, played between the legs, does not seem to have detracted from its feminine affect, again revealing some of the arbitrariness in the gender typecasting of instruments. The vogue for guitar-playing came and went at different times in different countries. Charles Burney tells an 
anecdote about the famous London harpsichord builder Kirkman who, worried about the devaluation of his instruments when ladies began trading them in to buy the latest fad-guitars-successfully reversed the trend by giving away numerous guitars to low-class women, which had the desired effect of giving the instrument a bad reputation. ${ }^{40}$

An interesting case of a "new" instrument, which became almost exclusively associated with female performers, was that of the musical glasses or armonica. Introduced in an improved form in England ca. 1761 by Benjamin Franklin, this instrument involved touching the fingertips to revolving moistened glasses of different sizes to produce a ringing tone. It was very popular on the touring circuit of the late 1700s, and even Mozart and Beethoven wrote pieces for it. Most of the performers were women, including the young English woman Marianne Davies, who used the glass harmonica, a gift from Franklin, as an accompaniment instrument for her sister, a singer; and the blind Marianne Kirchgessner, for whom Mozart wrote his Quintet, K. 617. As a relatively new instrument, the armonica did not have to fight against a centuries-long tradition of gender stereotyping and so could easily be taken up by female performers. It also helped to introduce the notion of travelling female instrumentalists to the European public.

In spite of the strong psychological pressure to conform to the norm of sexually appropriate instruments, there were always exceptions to the rule. Under certain circumstances, as in Italian convents of the late Renaissance era or the Venetian conservatories of orphaned girls during the Baroque era, women could be found playing "male" instruments. About the Venetian conservatories Charles de Brosses wrote: "[The girls] are reared at public expense and trained solely to excel in music. And so they sing like angels, and play the violin, the flute, the organ, the violoncello, the bassoon." 41 There were undoubtedly economic reasons for training these orphaned girls to perform in a novel way-in order to attract crowds to their concerts. Another group of women who had the opportunity to learn and perform non-traditional instruments were the daughters of professional players. For example, in France the daughters of such famous viol players as Sainte-Colombe, Marais, and Caix became quite accomplished performers (even on the bass viol) although they could never hold an appointment in the royal chapel. ${ }^{42}$ The Couperin musical dynasty produced many female organists over the course of almost two hundred years. No doubt the prominence of the family name helped to secure professional positions for several of the Couperin daughters. ${ }^{43}$ These exceptions just proved the rule that for the majority of women the choice of instrument was very limited indeed.

It was during the nineteenth century that the barriers against women playing such orchestral instruments as the flute, violin, and violoncello were gradually 130.

41 As quoted in Grout, A History of Western Music, 3rd ed., 404.

42 Julie Anne Sadie, "Musiciennes of the Ancien Régime," in Women Making Music, 205.

43Jane Schatkin Hettrick, "She Drew an Angel Down: The Role of Women in the History of the Organ 300 B.C. to 1900 A.D.," The American Organist 13, no. 3 (1979): 43. 


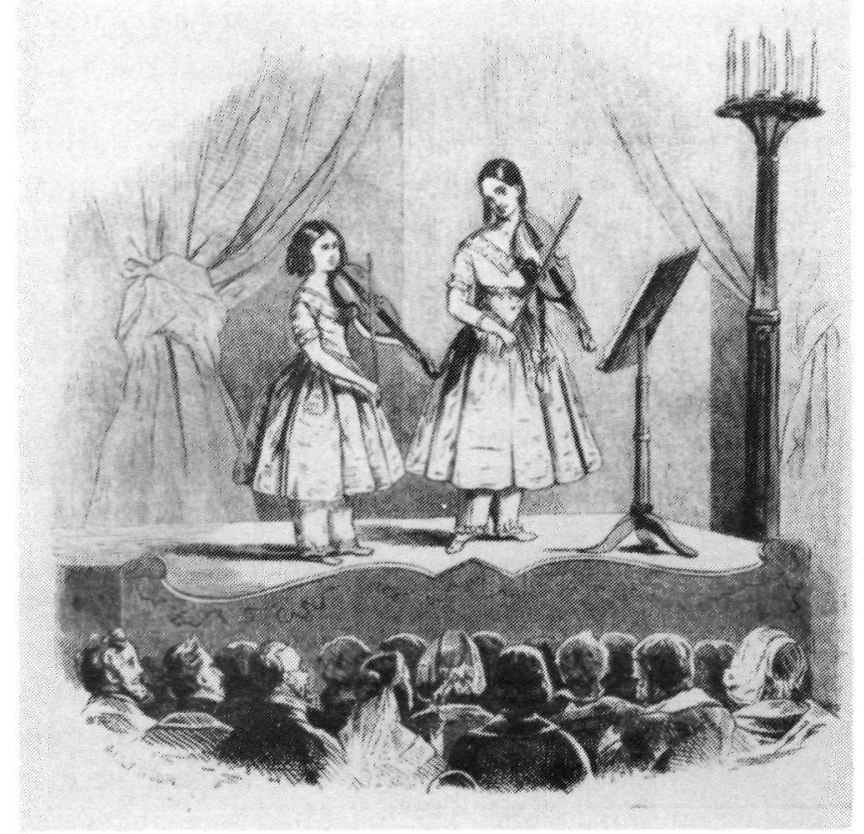

Figure 8. "The Italian Prodigies Maria and Teresa Milanollo," woodcut after a drawing by John Allanson, Illustrierte Zeitung (Leipzig, 1843), 1:201. Source: Heinrich W. Schwab, Konzert: Öffentliche Musikdarbietung vom 17. bis 19. Jahrhundert (Leipzig: Deutscher Verlag für Musik, 1971), 115.

broken down. This was also the period of revolutionary change in the structure of society: the decline of aristocratic and religious authority and the rise of a new monied middle class. One of the avenues leading to the dissolution of the old stereotyping of musical instruments was the advent of the touring child prodigy. ${ }^{44}$ The Mozart case was the inspiration to many fathers to train their children and put them on display in concert halls, often with great economic success. Since novelty was an important part of these circus-like affairs, the audience was often treated to the spectacle of a young girl playing the violin or flute. At first the young girls were forced to abandon their careers upon reaching puberty (as in the case of Nannerl Mozart or of the violinist Gertrud Schmeling, who nevertheless managed to switch her "instrument" and become famous as the singer Mara). But as the public grew accustomed to seeing more and more girls playing the formerly "male" instruments, the old stereotyping began to disappear-at least for the violin, violoncello, and lighter wind instruments. Figure 8 shows the two Italian sisters, Maria and Teresa Milanollo, performing as violinists before a packed audience in 1843--without the ruffled sleeves that so disturbed Junker. 
By the end of the nineteenth century, women were finally allowed to train at conservatories, and musical standards rose. However, they were still-with the exception of harpists-banned from joining traditional orchestras and chamber ensembles, since they posed a threat to the economic livelihood of male musicians, and so they formed professional all-women orchestras. ${ }^{45}$ These Lady Orchestras or "Damen Orchester" were especially popular in North America and continued at least into the 1940s. They gave women needed professional experience and, in order to fill in the ranks, encouraged young players to take up wind, brass, and percussion instruments. It was not until World War II, however, when the draft depleted the standard orchestras, that women were finally allowed entry, usually as violinists. Although the mixed orchestra is now the norm, there are still several well-known European orchestras that are reserved for males only.

In conclusion, the gender stereotyping of musical instruments was an important factor in hindering women from achieving an equal place with men as musical creators and performers. Women were limited to playing the "clavier" and such minor accompaniment instruments as the lute, harp, and guitar-and these only at the most dilettantish level. The major orchestral instruments-violins, winds, brasses - were all off-limits, as were the major performing ensembles, where most composers gained experience and public exposure. With such limited educational opportunities and no prospects for employment, how could a woman hope to become a composer? The woman's place was "in the home," and the gender stereotyping of musical instruments helped to keep her there.

\begin{abstract}
The sexual stereotyping of musical instruments in Italian, German, and English society from the beginning of the Renaissance period to the end of the nineteenth century is the object of this essay. Through evidence gleaned from iconography and a variety of written documents, the author demonstrates how the gender association of musical instruments virtually eliminated female participation from important musical activities, ensuring the male domination of the art and preventing women from becoming prominent composers.
\end{abstract}

45 Carol Neuls-Bates, ed., Women in Music: An Anthology of Source Readings from the Middle Ages to the Present (New York: Harper \& Row, 1982), 192. See also the excellent discussion in Judith Tick, "Passed Away Is the Piano Girl: Changes in American Musical Life, 1870-1900," in Women Making Music, 325-48, and Carol Neuls-Bates, "Women's Orchestras in the United States, 1925-45," ibid., 349-69. 